\title{
Language Impoliteness in Stand-up Comedy Academy (SUCA) II on Indosiar
}

\author{
Arie Yuanita \\ Universitas Negeri Surabaya \\ Surabaya, Indonesia \\ arieyuanita@unesa.ac.id
}

\begin{abstract}
This study aims to describe the impoliteness of the language used by the komika in Stand-up Comedy Academy (SUCA) II TV program in Indonesia, which aired on Indosiar. The data in this study are utterances containing language impoliteness conducted by komika in the Stand-up Comedy Academy (SUCA) II program, which aired in November 2015. Data were analyzed based on the taxonomy of impoliteness. The results showed that the komika often use impolite language in the form of harsh words to mock, insult, rebuke, curse, such as: thin, small, ondel-ondel pinrang, minions, hypocrites, village boys, tacky, chillies, weird, codot, crazy, preet, etc.
\end{abstract}

Keywords — language impoliteness; swear word; insult; rant

\section{INTRODUCTION}

Language impoliteness is a common thing nowadays, especially on television shows. Even the impoliteness of the language is deliberately carried out with the reason to entertain the audience and raise the rating of the event without regard to the negative effects that can occur if the impoliteness continues.

Stand-up comedy is one of the television shows that develops in public. Muzayyanah [1] states that Stand-up comedy is a humorous program that is delivered by speaking and relying on body movements. This type of humor has potential to enhance broad minded to the character of the comedian. The recent development of stand-up comedy in Indonesia is not only as a comedy show, but also used as a comedy talent search program. One of them is the talent search of stand-up comedy event on Indosiar or often called as SUCA.

Ironically, comedy programs that are entertaining instead have a lot of language impoliteness, such as: snapping, insulting, reproaching, underestimating, and so on. For example, in one of the SUCA II episodes entitled "Satan Teh Tubruk" a comedian named Cemen said: tacky.

1. Seriously, you really don't believe it, hayseed. Very

2. Other cities have typical foods and drinks, brebes has salted egg, Jakarta has egg crust, what does Cikarang have? "Cabe-cabean" catches optimus prime.

(Satan Teh Tubruk, Indosiar Stand-up Comedy, November 13th, 2015)
The use of abusive and impolite words is deliberately carried out and only a fiction scenario so that stand-up comedy looks more interesting and the scene looks reasonable. If this is shown continuously to the viewers, who are mostly teenagers and children, unconsciously this will be considered as true and justified. Furthermore, the language impoliteness may unconsciously be adopted in their daily behavior.

Therefore, the author is interested in describing the use of impolite language used by comedian at stand-up comedy. The problem to be discussed in this study is how the forms of language impoliteness in Stand-up Comedy (SUCA) II on Indosiar.

Language impoliteness is defined as a language activity which is aimed to damage interpersonal relationships or deliberately attack the face of the speech partner [2] [3] [4]. Culpeper [4] asserted that impoliteness is the opposite of politeness that is "the use of strategies that are designed to have the opposite effect - that of social disruption" or strategies used to damage social relations between speakers.

From perspectives of the impoliteness background, Culpeper [4] stated that there are several factors underlying the use of language impoliteness. The first factor is the social relations of the speaker and the speech partner who are very close or intimate. The closer they are, the greater the possibility of impoliteness. Another factor is the imbalance of power or social power between speakers. Speakers with more dominant social strengths will tend to be impolite to speech partners with weak social strength. The third factor is the desire of the speaker who deliberately does not want to keep the speech partner's face, which may be due to a conflict of interest.

Culpeper [4] developed concepts of impoliteness strategies as strategies that are contrary to the politeness strategy according to Brown and Levinson [5], namely:

(a) bald on record impoliteness is an impoliteness strategy that is deliberately carried out openly without regard to the speech partner's face,

(b) positive impoliteness is a deliberate strategy to threaten the positive face of the speech partner, such as:

a. ignore others,

b. excommunicate others,

c. withdraw or separate from the speech partner who does not have the same opinion as himself or his group,

d. show or express feelings of disinterest, 
e. use inappropriate designations or nicknames to speech partners or call them with insulting names or nicknames,

f. use jargon or slang so that other people outside the group cannot understand the conversation, make others feel uncomfortable with the language they use,

g. use taboo, curse words or harsh language.

(c) negative impoliteness is a deliberate strategy which is aimed to threaten the negative face of the speech partner, such as:
a. flout, criticize or mock,
b. insult others and treat them arbitrarily,
c. underestimate or demean others,
d. explicitly relate to speech partners with negative things.
e. makes it seem as if someone is indebted to the speaker.

(d) mock politeness is a strategy of artificial politeness or pretended,

(e) withhold politeness, an impoliteness is caused by the absence of politeness that should exist.

Research on language impoliteness has been investigated by Itsvan Kecskes [6] in an article entitled "Intercultural Impoliteness" which states that language impoliteness in each culture can be different. Language impoliteness occurs implicitly and is influenced by context or situation. There is also, Marta Dynel [7] in her article entitled "The Landscape of Impoliteness Research" which discusses how impoliteness occured and disseminated through computers. In addition, Kunjana Rahardi et al [8] in an article entitled "Pragmatic and Linguistic Studies of Impoliteness in Language" that discusses how the form and meaning of pragmatic and linguistic impoliteness contained in the realm of religion.

\section{METHODS}

This research uses a qualitative approach with descriptive type or can be said to be descriptive qualitative. The research method used is the referential equivalent method [9]. This method is used to describe the language impoliteness used by comedian in Stand-up comedy on Indosiar. The impolite languages that will be the objects of research are taboo, swear language, and the use of utterances to express certain speech acts such as insulting, rebuking, criticizing, cursing, scolding and etc which are considered as deliberate language used to damage relations between speakers.

The data in this study are utterances containing language impoliteness conducted by the comedians in the Stand-up Comedy event on Indosiar, which aired in November and December 2015. The source of this research is the speech in the Stand-up Comedy (SUCA) program II Indosiar in episode of Metropolitan VS Cewek Cikarang Girls, Millionaire Pending, Satan The Tubruk, and Cemen VS Musdalifah. Subsequent research data were transcribed and then analyzed based on the taxonomy of language impoliteness [4].

\section{RESULTS AND DISCUSSION}

\section{A. Impoliteness of Language}

From the four language impoliteness strategies by Culpeper [4], the negative impoliteness strategy ranks highest, which is then followed by the second rank, the positive impoliteness strategy. The negative impoliteness that is most often used are to flout, mock, insult others and treat people arbitrarily, underestimate or demean others, and explicitly associate others with negative things. The most positive impoliteness used are the use of curses with harsh words, and the use of inappropriate or insulting nicknames. The following is a discussion of some research data related to positive and negative impoliteness strategies that are mostly used by comedian in Stand-up Comedy on Indosiar.

\section{B. Positive Impoliteness}

This strategy is used by the speaker to damage the positive face of the speech partner. Positive face means the desire of each individual to be respected, valued, desired and needed by others. Sample data 1-4 (Cemen VS Musdalifah, Stand-up Comedy Indosiar, November 14th 2015)

1. This Cemen's stand-up style is weird like anything. When he speaks, it looks like a person is eating with bone aches.

In the data above, there are some impolitenesses that indicate a feeling of disaffection with the speech partner. Speakers attack the opponent's positive face by calling the other person as a freak and speaking like a bone-strained person.

2. Cemen's stand up style is like that, for your information, if you become a dangdut singer, don't be upset, later if your self-introduction becomes chaotic, well I'm Julia, I'm Peres, I will be pressured. That material does not educate others.

In the data above the speaker attacks the opponent's positive face by mentioning the other person as a person who does not educate.

3. Therefore, if my mom advises me, there are needs for her to bend and woobles like this, don't be naughty, don't be naughty all the time, keep on learning so that you can be smart.

In the data above, there is language impoliteness, that is, there are needs for her to bend and wobbles like this, which refer to the interlocutor as someone who always advises using twists and wobbles like a dangdut singer which will cause the interlocutor feels uncomfortable.

4. Now, today I was told to beattle like this, as same as this kid, here is musdalifah, the beautiful woman is still being questioned, the size is tiny, the term is minion, huh?

In the data above there are some impolitenesses in the form of mentioning or nicknaming to inappropriate speech partners. Speakers attack the opponent's positive face by calling the other person as a kid, minion and woman whose beauty is still questionable. 
Sample data 5-9 (Satan Teh Tubruk, Stand-up Comedy Indosiar, 13th November 2015)

5. But if you see it again, it's not a park but a sidewalk, right? Cikarang people think the sidewalk as a park. They think it may heaven. Wow, I am in heaven, so happy for this life. So crazy.

The data above contains words that are not only harsh but also highly demeaning to others like going crazy. In the speech the speakers call others crazy.

6. If he does not back off, tell him again, hmm, codot, pull back a little, i punch you if you don't do that. I'm sensitive due to menstruation.

In the data above, one of the comedian uses a curse to express his anger, that is, codot and tampol (punch). Codot word is used to swear as an example of the data above, the word eye contains a very rough meaning.

7. Mama please stand up. Now this is the figure of exdangdut singer. Next to her is the legend of "tukang nyawer",

In the data above there are some impoliteness in the form of mentioning inappropriate speeches eventhough the person is his parents. Speakers attack the opponents' positive faces by referring to the other person as a dangdut singer and legendary "tukang nyawer".

8. I am afraid when my parent like dangdut until they are making out, they are singing. My father sings "when you are beside me with a heart of solitud" then, my mother replied "I give you my body and soul, I obey everything you ask for."

In the data above the speaker attacks the positive face of his parents by calling his parents always making out with the dangdut song and will cause discomfort for both of them

9. In the past, my parent was busy thinking negatively all the way to me, my body was as thin as this, supposed to be a drug addict ashtaghfirullah mama. I did not tried the ecstasy pills,

In the data above, there is language impoliteness, that is mentioning his parent who always full of negative thinking. It will cause discomfort for the parent.

\section{Negative Impoliteness}

Unlike negative politeness that serves to protect the negative faces of the speech partners, keeping them from being disturbed, negative impoliteness aims to damage the negative face which is to disturb the individual's desire to not to be disturbed.

Sample data 11-15 (Cemen VS Musdalifah, Stand-up Comedy Indosiar, 14 November 2015)

10. I am on stand-up beattle right now and mas cemen, I am confused, what's the good thing on you, this friend, he's already "keris" eh, i mean he's thin, small, like a flute.
In the data above there are some impoliteness in the form of ridicule and reproach towards the interlocutor. Speakers call the interlocutor as a person who is not good and thin, small like a flute.

11. And I tell you, this cemen is a hypocrite, he often talks about dangdut songs even though he doesn't understand dangdut at all.

In the speech above, the speaker insults or mocks the interlocutor. Speakers mock the speaker as a hypocrite. The speaker treats other people arbitrarily.

12. He only discussed about dangdut so that he could take the opportunity with sexy choirs.

In the data above there is a language impoliteness which is taking the opportunity with sexy choirs. The speaker calls the interlocutor as a person who is always thinking negatively and it can cause the interlocutor to be uncomfortable.

13. But it canceled because of the Musadalifah's singing. What a wobble is that, it is like ondel-ondel pinrang.

In the speech above, the speaker insults or mocks the interlocutor. Speaker mocks the opponent's wobble as Pinrang's ondel-ondel wobble. The speaker treats other people arbitrarily.

15. When I become a singer, I don't use money but I use credit while I ask, how many pulses you want? Just 20 , bro. Which number? the one behind it is 94 . How come it hasn't entered yet?

In the speech above, the speaker insults or mocks the interlocutor. Speakers mock the opposing speaker as a singer who is "disawer" using 20,000 pulses. The speaker treats other people arbitrarily.

Sample data 16 (Millionaire, Stand-up Comedy Indosiar, 16th December 2015)

16. Does anyone know me? ... Hypocrisy ... the first winner.

In the data above, speakers mock and ridicule the opponents with the word hypocrite. The word hypocrite is used to swear like the sample data above which contains very rude meanings.

Sample data 17-18 (Satan Teh Tubruk, Stand-up comedy Indosiar, 13th November 2015)

17. Seriously, you really don't believe it, hayseed. Very tacky.

The data above contains words that are not only harsh but also highly demeaning to others, for example the hayseed. The comedian also mocked by calling the other person as tacky.

18. Other cities have typical foods and drinks, brebes has salted egg, Jakarta has egg crust, what does Cikarang have? "Cabe-cabean" catches optimus prime.

In the statement, speakers mock or ridicule the Cikarang people. Speakers insulted the Cikarang's 
people for producing chillies. The speaker treats other people arbitrarily.

Sample data 19-22 (Metropolitan VS Cikarang Girls, Stand up Comedy Indosiar, 2 November 2015)

19. Besides, it's really weird going on a Twitter, isn't there a boarding house? ... for playing Twitter too ... you are a pervert.

In the speech above, the speaker mocks or insults the other person. Speakers mock the another speaker as a pervert. The speaker treat other people arbitrarily.

20. I'm really jealous of my girls now. So what I have to do is I have to get permission first. If I want to eat, I have to ask permission first. It's like an elementary school kid not going to school. Why, if I don't ask for permission, I can't take a part because of lack of attendance, my girlfriend is a lecturer, okay?

In the statement, the speaker mocked his girlfriend as a jealous person. He said that if he wants to do aything he has to ask permission from her and mock his girlfriend like a lecturer who must ask permission and report.

21. I imagine if my girlfriend turns into a cell phone with a treetball type, her nose is qwerty, her lips are touchscreen, if I kiss her ...

In the data above, the speaker behaves arbitrarily towards his girlfriend by saying his girlfriend is like a cellphone.

22. Woi woi woi wae all of you, you're so tacky In the data above the speaker insults the interlocutor by calling the interlocutor a tacky person.

\section{CONCLUSION}

Based on the analysis that has been done, it can be concluded that in the Stand-up Comedy discourse on Indosiar, the negative impoliteness strategy ranks highest, which is then followed by the second rank, the positive impoliteness strategy. The negative impoliteness that is most often used is to mock, to ridicule, to insult others and to treat people arbitrarily, underestimates or demean others, and explicitly associate others with negative things. The most positive impoliteness used are the use of curses with harsh words and the use of inappropriate or insulting nicknames

\section{REFERENCES}

[1] F. Muzayyanah, Skripsi: Retorika Dakwah Dalam Tayangan Stand-up Comedy Show Metro TV. UIN Sunan Kalijaga: Jakarta, 2014.

[2] D. E. Archer, Verbal aggression and impoliteness: related or synonymous?" Impoliteness in Language: Studies on its Interplay with Power in Theory and Practice. Eds. Derek Bousfield dan Miriam A. Locher. Berlin: Mouton de Gruyter, pp. 181-210, 2008

[3] M. Terkourafi, Toward a unified theory of politeness, impoliteness, and rudeness. Impoliteness in Language: Studies on its Interplay with Power in Theory and Practice. Eds. Derek Bousfield dan Miriam A. Locher Berlin: Mouton de Gruyter, pp. 45-76, 2008.

[4] J. Culpeper, "Toward an anatomy of impoliteness," Journal of Pragmatics, vol. 25, pp. 349-367, 1996.

[5] P. Brown and S.C. Levinson, Politeness: Some Universal in Language Usage. Cambridge: Cambridge University Press, 1987.

[6] I. Kecskes, "Intercultural Impoliteness," Journal of Pragmatics, vol. 86, pp. 43-47, 2015

[7] M. Dynel, "The Landscape of Impoliteness Research," Journal of Politeness Research Language Behaviour Culture, vol. 11, pp. 329-354, 2015.

[8] K. Rahardi, et. al., Kajian Pragmatik dan Linguistik Ketidaksantunan dalam Berbahasa. Yogyakarta : Universitas Sanata dharma, 2015.

[9] Sudaryanto, Metode dan Aneka Tehnik Analisis Bahasa. Yogyakarta: Duta Wacana University Press, 1993. 